\title{
IS KRAKÓW A SMART CITY YET? ANALYSIS OF THE EFFECTIVENESS OF IMPLEMENTING THE SMART CITY CONCEPT IN KRAKÓW
}

\author{
Julia Gorzelany, Stanisław Lorek
}

\section{Summary}

Cities play a fundamental role in the economic development of the country. The vast majority of jobs, innovations and services are concentrated in the cities, thereby determining the country's economy. Currently, the Smart City is the key concept of sustainable urban development throughout the world. It covers a broad spectrum of issues related to effective, sustainable city management. Today, Kraków faces important challenges in the field of socio-economic and functional development. For years, the city's authorities have been undertaking activities aimed at making Kraków a smart and modern metropolis, based on scientific potential, while maintaining the unique historical and cultural heritage. The aim of the present work is to analyse the effectiveness of implementing the Smart City concept in Kraków. To achieve that goal, the most important resources, challenges and development aspirations of Kraków have been examined. The strategic objectives set out in the Kraków Development Strategy and the degree of development of selected elements and systems of the city were also analysed. An important element of the work is a questionnaire-based survey carried out among the residents of Kraków. The results of the analyses do not fully confirm the effectiveness of the measures implemented. A city that aspires to become a strong European metropolis should improve solutions to its current development problems, the most important of which include air quality and transport nuisance.

\section{Keywords}

smart city • development of the city • sustainable development • city development strategy • smart governance

\section{Introduction}

Kraków is currently facing important challenges in the field of socio-economic, but also functional, development. For many years now, the city's authorities have been taking steps to turn Kraków into a smart and modern metropolis, based on scientific potential and knowledge-based economy, while maintaining the unique historical and cultural heritage. In 2013, work began on the construction of a new development strategy, based on the Smart City concept. The stakeholders - residents of the city - were also involved 
in the process of creating the document. They participated in various meetings, consultations, workshops and conferences organized by the municipal authorities, with the participation of scientists from Kraków's universities specialising in the issues of urban and regional development. One of the elements of social participation within the work on the new development strategy was a survey among Kraków's residents regarding their opinion on the quality of life in the city.

The aim of the present work is to assess the effectiveness of implementing the new Kraków Development Strategy. In respect to the goal thus defined, the following research questions were constructed:

- Does Kraków have the adequate potential for it to be defined as a Smart City?

- Are there adequate conditions, regarding the quality of life in Kraków?

- Is Kraków attractive from the points of view of residence, work, and leisure?

- Is Kraków able to attract new residents and entrepreneurs?

\section{An attempt at defining the Smart City concept}

Effective planning of the sustainable development of a modern city in the era of globalization - along with the related economic, social and functional transformations - is a serious challenge faced not only by city authorities but also by other stakeholders and participants in the urban space. An important element of development planning is the analysis of functional connections that take place between metropolises, but also between the metropolis and the surrounding functional area, followed by the best possible use of these connections, in order to undertake partner projects. Cities anchor their development in the visions and goals defined in their development strategies, which are very often vague and general, and therefore do not match the actual opportunities and needs, as well as lacking references to good practice models, tested and proven elsewhere.

Currently, one of the leading visions of sustainable urban development throughout the world is the concept of a Smart City, covering a broad spectrum of issues related primarily to effective, sustainable city management. This concept can be identified with the English terms Intelligent City and Smart City, which are used interchangeably in the literature on the subject. These terms will also be treated as one and the same in the remainder of this work.

There does not exist one widely accepted definition of the Smart City, although among many attempts to explain this concept, one common element comes to the fore. Namely, it is universally agreed that the concept of the Smart City should not be limited only to the implementation of modern technologies, as it is a much broader issue. It concerns modern spatial planning, environmental protection, stimulation of economic development, but also effective investment in the city's development, translating into savings that can be reinvested in the future. The main goal of the Smart City idea is to improve the quality of life for its residents, and the better functioning of the city [Bieńkowska et al. 2015]. 
According to Kowalski [2012], the concept of an Intelligent City should not be fully identified with the idea of a sustainable city. Although in both cases the emphasis is placed on the necessity of rational management of human and natural resources, nevertheless the basis for the first of these concepts lies in the use of the latest technology achievements in the field of IT, teleinformation, GPS and GIS. When implementing such solutions, one should remain critical, as some of them may turn out to be more or less controversial, for example by inadequate limitation of privacy in the public space of the city, as compared to the actual need thereof, or their maladjustment to the economic or social conditions of the given urban centre or the given state.

Furthermore, according to Jać and Zapolska [2015], the Smart City concept is currently one of the methods of city parameterization and management, therefore it should be considered in an interdisciplinary approach, because depending on the selected approach, the focus can shift to attributing it with social, economic, or technical significance.

In the era of current changes, cities (including European urban centres) encounter many barriers that can be generally identified as developmental difficulties. These are first and foremost: pollution of the natural environment; production of excessive waste; insufficient infrastructure, ill adapted to contemporary needs; scarcity of resources; as well as increasing expectations of residents in relation to the living conditions in the city, broadly understood. In this context, the concept of Smart City is treated as a kind of a model or blueprint, or an algorithm of behaviour that can counteract these difficulties [Jarzemska et al. 2011].

Smart City according to Kukliński and Woźniak [2011] can be understood as a specific and intelligent structure that is able to react quickly to changes taking place within the urban space and to newly emerging local needs. Mazerant [2012] believes that the concept of an Intelligent City assumes the existence of the specificity of local conditions and potentials of urban and metropolitan centres, which are treated as a reflection of the modern approach to the topic of city management and city evolution. Parteka [2012], on the other hand, assumes that the Smart City idea should focus above all on the issue of the more efficient use of resources. This applies primarily to energy policy, public security, conservation of natural resources, and transportation network.

The implementation of the Smart City concept therefore requires the employment of integrated processes and activities as well as the use of state-of-the-art technologies in the best possible ways. In order to develop appropriate procedures necessary to manage an urban centre, it is necessary to involve all city stakeholders or participants to co-decide on the key issues, of crucial importance for the city [Wdowiarz-Bliska 2012].

Contemporary Polish cities are struggling with many problems, the causes of which arise, inter alia, from socio-economic changes, demographic changes, uncontrolled urbanization, growing pollution of the environment, and growing needs related to consumption. Solving the above problems should be the priority, the main goal and task of the Intelligent City. Unfortunately, there is no ideal development pattern that could be universally applied for all cities. Bearing in mind the development potential of a given city, its specificity, its individual conditions and possibilities, an indi- 
vidual, unique concept should be developed, intended for the particular urban centre [Gorzelany-Dziadkowiec et al. 2015].

Dirks and Keeling [2009] propose the execution of several stages of work related to the creation of an optimal concept of city development, based on the Smart City concept. The initial stages refer to a detailed analysis of the strengths and weaknesses of the city, its opportunities and threats, as well as the determination of its specialization and directions for development. Another important element is the assessment of the degree of development of the city's various elements and systems. Further points include the use of available, modern technological solutions and good practices applied in other cities that have already successfully implemented their development concepts. The final stage should be the creation of a new development strategy, with the proposal for new solutions, adapted to the specificity of the particular city and the problems that arise within it. In addition, a key role in creating a Smart City is the cooperation between all stakeholders, or participants in the urban space, including the city's governors, residents, businesses and universities. Only the involvement of all local actors in developmental changes can bring about a real chance to make the desired changes.

\section{The key resources and development aspirations of Kraków city}

Kraków is a city of exceptional cultural importance, not only in Poland, but also on a European and global scale. The city is distinguished by many unique features, the most important of which is the rich cultural heritage. The former capital and the seat of Polish kings is today a city with a unique brand and a unique image, attracting crowds of tourists from the most distant parts of the world.

In accordance with the spatial policy of the European Union and the Concept of the Spatial Development of Poland 2030 [Koncepcja Przestrzennego Zagospodarowania Kraju 2030], Kraków belongs to the centres of primary importance for the settlement network and the country's economy. It is included in the group of 72 MEGA cities, or Metropolitan European Growth Areas. While analysing the supra-regional position of Kraków, it can be stated that the city together with its metropolitan area, in conjunction with the adjacent and strongly urbanized province of Silesia, constitute a spatial unit characterized by economic development that is intensive, on European scale. Kraków is also an important transportation hub - not only within the country, but also throughout Central Europe.

In accordance with the "Kraków Development Strategy. Here I want to live. Kraków 2030” [Strategia Rozwoju Krakowa. Tu chcę żyć. Kraków 2030], the city’s economic development and the increase in the quality of life of its residents is conditioned by a number of factors that constitute the unique assets of Kraków. The most important resource of the city lies in its human capital. Kraków is currently distinguished by the lack of threat of negative demographic trends compared to most cities in Central Europe, and it is the space of "conscious choice of place to work and study, but also to live in and to spend one's free time". The city has many advantages that are attractive to creative, entrepreneurial and educated people. 
The Kraków Development Strategy, defining the challenges and specifying the directions of the city's development, indicates the aspirations of residents and local authorities alike to build Kraków's future as a strong, economically competitive and sustainable centre. It is also important to nurture the genius loci of Kraków, which is related to the quality of life of the inhabitants.

The first of the aspirations is to undertake appropriate activities aimed at making Kraków one of the two most important cities in Poland. When analysing the demographic, socio-economic and cultural potential, we come to the conclusion that Kraków is currently second only to Warsaw. The city is characterized by unique metropolitan functions, thus it enjoys an either indirect or direct impact not only within the region and the country, but also throughout Europe. It is a "locomotive" town, reinforcing the development of the region. However, taking into account the pace of growth of other Polish metropolises, especially Poznan and Wrocław, it should be assumed that insufficiently strong development of the city may, in the long term, lead to the risk of Kraków losing its second position throughout the country.

The aspirations of all participants in the urban space of Kraków should focus on creating a city of the future that will guarantee maintaining a high quality of life, and the city's genius loci; a friendly place to live, work, and relax. Furthermore, Kraków aspires to be the leader in areas such as fulfilling symbolic functions and those related to the leisure industry. The city strives to create a contemporary culture that will develop within the local artistic milieu, and cultivate the image of the most recognizable Polish city.

All these ideas, aspirations and ambitions are part of the most popular development concept for the city, which is sustainable and intelligent development. "Kraków Development Strategy. Here I want to live. Kraków 2030" [Strategia Rozwoju Krakowa. Tu chcę żyć. Kraków 2030], is a new document adopted by Resolution No. XCIV/2449/2018 of the Kraków City Council of February 7, 2018. Thereby, development assumptions in line with the Smart City concept have been adopted, with particular emphasis on these development resources, on the basis of which Kraków is able to effectively compete with other centres - for prestige, for new investments, as well as for current and potential residents.

\section{Opinions of the inhabitants regarding the quality of life in Kraków}

The document of the "Kraków Development Strategy. Here I want to live. Kraków 2030” [Strategia Rozwoju Krakowa. Tu chcę żyć. Kraków 2030], was created as a result of cooperation between many groups and milieus, conducting open debates, very often with the participation of Kraków's residents. One of the forms of citizen involvement in the work on the strategy was to conduct a poll aimed at getting to know the opinion of the Kraków's public on the quality of life in the city, and on their expectations regarding the city's development directions. The poll began on 19 September 2013, lasted one month, and it used three techniques, namely: a street survey, an online survey, and a paper survey. 1004 respondents took part in the street poll, and 5507 people responded to the online and paper surveys [Fulbiszewska et al. 2013]. 
One of the elements of the implementation of the assumptions adopted in this work is the analysis of the current opinion of Krakovians regarding the quality of life in their city. For this purpose, a questionnaire-based survey was carried out, based on the structure of questions included in the aforementioned opinion poll, commissioned by the City of Kraków in 2013. The survey, in the form of an anonymous online questionnaire, was carried out between 13 March 2018 and 12 June 2018. During this time, 211 respondents completed the questionnaire. An additional element introduced into the questionnaire was the diversity of respondents depending on their professional affiliation with such areas as architecture, urban planning, spatial management, geodesy and public administration. These persons as well as students of the above mentioned dsiciplines were included in the group of "experts" who - in the number of 89 - constituted $42.2 \%$ of the overall number of respondents.

The main objective of the questionnaire-based survey was to compare the opinions of Kraków residents in the most important areas of the city's functioning, dating to the time of commencement of works related to the construction of the new Kraków Development Strategy, with their current opinion or evaluation of the situation after the adoption of the strategy based on the Smart City concept.

Among the respondents in the survey in 2018, the majority were women, constituting 55\% of all respondents. The largest group - slightly more than $44 \%$ - were people between 18 and 29 years of age; only slightly fewer respondents were between 30 and 49 years of age; whereas the smallest group of respondents (less than 1\%) were people over 65 years of age. The vast majority of respondents (59.2\%) had a university degree. The second biggest group (over 34\%) were people with secondary education. Among those participating in the survey, there were 8 persons with a $\mathrm{PhD}$ degree or higher. Over half of the respondents (58.2\%) remained professionally active. The number of pupils and students is also significant, as they constituted almost $30 \%$ of all respondents.

Among the many issues covered by the survey, regarding the attractiveness of Kraków from the point of view of residence, work, and leisure, there were questions about the condition of the natural environment as a whole, about the condition and number of green areas, as well as the city's cleanliness and aesthetics. Issues related to the access to culture, sports, and recreation services were also discussed, as well as the functioning of educational services for children, the medical services and the quality of public services provided in municipal agencies in the city.

Undoubtedly, the highest rated aspect of the city's offer addressed to its residents is the cultural services such as cinemas, theatres, concerts, exhibitions, etc. Over $22 \%$ of respondents were very satisfied and over half (50.2\%) were satisfied with the offer in this area. Every fourth person issued an average rating.

The area which, apart from the quality of the environment, was ranked the lowest in this part of the survey, was related to moving around Kraków by car, bicycle and on foot. Driving - or motorized traffic - was rated the lowest. In this latter respect, as many as $71.5 \%$ of respondents are dissatisfied, and $22.7 \%$ participants in the survey issued an average rating. 
The conditions offered by the city of Kraków to its inhabitants in terms of the level of safety, business, and labour market have not been assessed highly. The average rating was the most frequently chosen.

A relatively low assessment of the quality of work of municipal offices and public institutions in the earlier points of the questionnaire was also confirmed in responses to the question about the opinion on the care and attention of Kraków authorities to the quality of life of the city's residents. Average rating was issued by $52.1 \%$ of the respondents and by $62.2 \%$ of experts, compared to $51 \%$ in 2013 . There was a slight increase in the low rating, compared with the survey from five years earlier - and low rating was issued by $17.7 \%$ more people surveyed in 2018 .

Other areas included in the survey were the directions of Kraków's development, and development challenges of the city. In terms of Kraków's directions for development, the majority of respondents chose mainly such areas as: culture and art $(29.4 \%)$, science $(19.7 \%)$, tourism $(18.3 \%)$, new technologies $(15.2 \%)$, and business $(10.9 \%)$, and no significant differences were observed, either compared to the 2013 assessments, or compared to the sub-group of experts.

Much bigger differences have been observed in the opinion of Kraków's residents regarding the development challenges faced by the city of Kraków. In the survey carried out in 2013, the challenge related to the quality of public transport came to the fore, with a score of $33 \%$. Currently, a similar result $(31.3 \%$ and $33.5 \%$ in the expert group) concerned ecology and air cleanliness in Kraków. Other important development challenges included: communication (24.4\%), spatial order and aesthetics (15.2\%), economy and development based on innovations (13.2\%), and safety $(7.6 \%)$.

\section{Determination of the degree of development of Kraków in the view of the Smart City concept}

Benchmarking analysis, serving to position the given urban centre compared to other cities in the field of the effectiveness of implementing the idea of an Intelligent City, was created by a team of the Technical University in Vienna under the direction of prof. Rudolf Giffinger, Florian Strohmayer and Hans Kramer, working on issues of Smart Cities since 2007, for the purpose of creating the European Intelligent City Model. This model makes it possible to adopt a comprehensive approach to the classification and comparative analysis of European cities in the context of implementing the concept of development based on the Smart City idea. Currently, the fourth version of the Smart City model is available, based on data from 2015. It identifies 6 areas in the city's functioning, facilitating the analysis of its level of development, namely: smart economy, smart governance, human and social capital (smart people), transport and communication (smart mobility), sustainable environment (smart environment), and quality of life (smart living).

In addition, within the six aforementioned areas, 27 factors were identified, for which 90 indicators were adopted. This made it possible to use the standardization 
method in order to obtain normalized values for each of the city's functioning areas, as well as to obtain average values for each city.

The study covered a total of 90 cities from 21 countries and populations ranging from 300 thousand to 1 million inhabitants. The Polish cities, which were subjected to the analysis, included: Bydgoszcz, Gdańsk, Katowice, Kraków, Łódź, Lublin, Poznań, Szczecin, and Wrocław.

In the case of Kraków, the analysis included a total of 88 indicators that were obtained from the following sources: Eurostat, "City audit" and "Perception of the city audit” reports, Eurobarometer, ESPON, and MastersPortal.eu [Bieńkowska et al. 2015].

Figure 1 presents the profile of Kraków in the form of a radar chart, concerning six key dimensions of Smart City functioning, against the background of average values calculated for all ninety European cities subjected to the analysis.

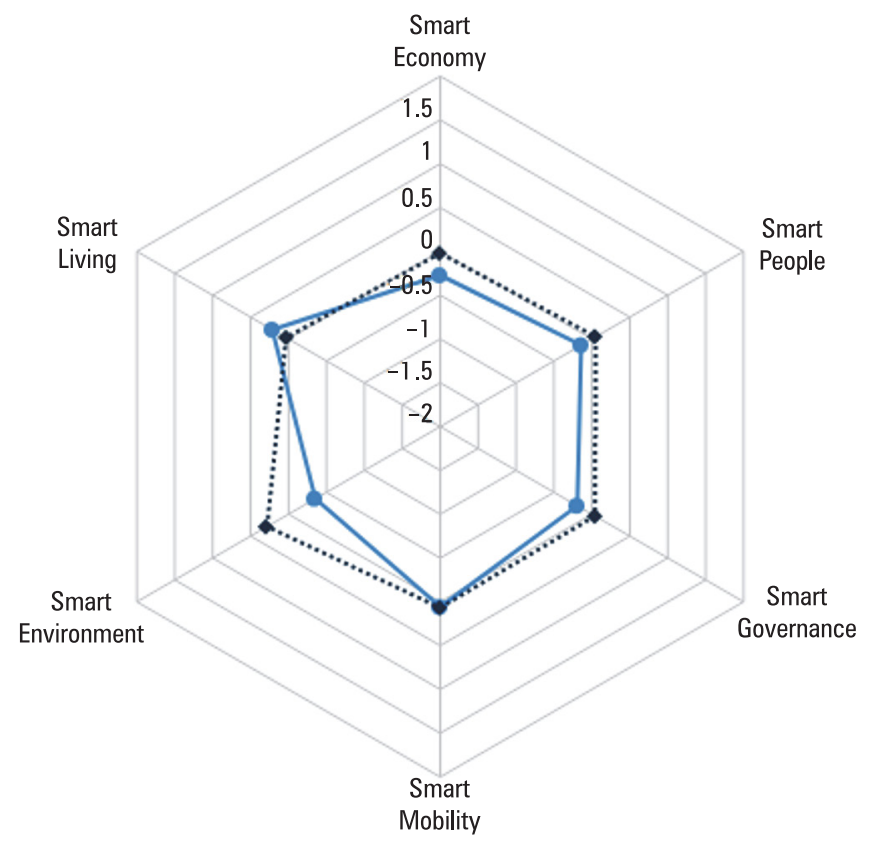

Source: www.smart-cities.eu

Fig. 1. Profile of Kraków city against average values of all the cities that were subjected to the analysis

In the key area of the quality of life, i.e. "smart living", Kraków obtained the best results both in terms of comparison against the average for all the analysed cities, and in comparison against all Polish cities. In the case of Kraków, the distribution of values 
of individual indicators, by means of which the average for the quality of life area is determined, is rather heterogeneous. Clear deficiencies are observed in indicators related to health conditions and air quality, whereas the strengths of Kraków include issues related to individual safety and the high standard offered by educational centres.

In the smart economy area, Kraków holds a leading position in the group of Polish cities. Unfortunately, this does not mean a good result in comparison with other European countries. The relatively clear difference that separates Kraków from the average for all ninety cities across Europe is mainly due to a poor result in terms of indicators such as the "spirit of innovation" and the low survival rate of start-up companies. The asset of Kraków in the field of economy is entrepreneurship. This is particularly noticeable in the growing self-employment rate, as well as the increase in the number of newly created start-up companies [Giffinger et al. 2007].

The weakest result is shown by the capital of the Małopolska region in the area of smart environment. Standardized value, which consists of such factors as: air quality, ecological awareness and sustainable management of natural resources, significantly differs from the average for all examined cities. Low air quality, especially in autumn and winter, caused by high concentration of dust in the air and producing smog, is the main reason for the low values shown by Kraków.

Smart mobility is another area that determines the degree of Smart City development, comprising sustainable transport and communication. The result achieved in this area is comparable to the average for all the analysed cities, and it is better than the indicators shown by other Polish cities. Kraków's small deficiencies in this area concern the "sustainable transportation system", which is caused by a significant share of private transport in the city's transportation system, and a low level of safety on Kraków's roads. On the other hand, the ICT infrastructure is well developed [Bieńkowska et al. 2015].

The situation of Kraków in the area of smart people shows the greatest deficit in factors related to lifelong learning, which is likely to mean that Krakovians rarely continue their education, and they do not often consult literature, particularly the specialist one. In terms of indicators related to "open mind" of the residents, the situation is much better. This means that the inhabitants of Kraków often use modern forms of communication with public institutions, and also, that European awareness and a positive attitude towards foreigners are rooted in the local population. There are no significant differences in this area compared to the remaining eight Polish cities, while Kraków's result in the field of smart people is slightly lower than the average calculated for all cities studied [Giffinger et al. 2007].

In the area related to intelligent management, Kraków's performance in relation to the average value for all the analysed cities, and for the group of Polish cities, is very similar to the result achieved by the capital of Małopolska in the field of smart people. The lowest result refers to indicators related to pro-European activity, and to women's involvement in public affairs of the city. A much higher result was awarded to the city in terms of efficient and transparent administration. 


\section{Conclusion}

Contemporary cities are currently facing complex challenges in the field of socioeconomic development. One of the leading visions of sustainable city development is a concept based on the idea of Smart City, consisting mainly in focusing on those resources of the given urban centre, which allow it to compete for new residents and investments.

The aim of the present work was first of all to assess the actions taken by the city authorities towards making Kraków a smart and sustainable city. Bearing in mind the studies and analyses carried out in this work, it can be stated that the effectiveness in the implementation of a development strategy based on the Smart City concept by Kraków authorities remains average. Although the assumptions set out in the strategic documents establish the correct directions for the development of the city, the most important development problems of Kraków still remain important barriers, limiting the inflow of new residents and investment projects to the city to a significant extent.

The research carried out in this work shows that Kraków does not deviate significantly from the average values calculated for European cities in terms of the level of "intelligence". Although the "smart living" indicator takes a value that exceeds the aforementioned average, the aspect related to the quality of the environment (smart environment) significantly reduces Kraków's ranking among other cities due to their "intelligence". The situation looks even worse compared to those urban centres, which in the literature on the subject are quoted as model examples of Smart Cities. Based on that, Kraków can now be considered as a "medium-intelligent" city.

The assessment of city management, and the creation of appropriate conditions regarding the quality of life by the city authorities, was determined by the residents both during the survey in 2013, and the one in 2018, to be at the medium or low level. In the opinion of the local community, the biggest problems - which at the same time constitute developmental barriers for Kraków - include: low quality of the natural environment, mainly air pollution; transport and communication nuisance; and insufficient care and attention of the city authorities to the quality of life of its citizens. Despite this, Kraków is constantly enjoying the position of the city, which is attractive from the point of view of residence, work, and leisure, and which enjoys the potential that is able to attract new residents as well as entrepreneurs. This is undoubtedly caused by the genius loci of Kraków, and the uniqueness of the city resulting from its rich historical and cultural heritage.

\section{References}

Bieńkowska D., Ulasiński C., Szymańska J. 2015. Strategia SMART_KOM, czyli mapa drogowa dla inteligentnych rozwiązań w Krakowskim Obszarze Metropolitalnym, Centrum Doradztwa Strategicznego s.c. D. Bieńkowska, C. Ulasiński, J. Szymańska, Kraków.

Dej M. i in. 2016. Rozwój gospodarczy. Raport o stanie polskich miast 2016. Instytut Rozwoju Miast, Kraków. 
Dirks S., Keeling M. 2009. A vision of smarter cities. How cities can lead the way into a prosperous and sustainable future. IBM Institute for Business Value, https://www-03.ibm.com/ press/attachments/IBV_Smarter_Cities_-_Final.pdf [accessed: 04.07.2018].

Fulbiszewska M., Lesińska E., Pytliński Ł. 2013. Mieszkańcy Krakowa. Opinie na temat życia w mieście. Wyniki badania opinii publicznej, przeprowadzonego wśród mieszkańców Krakowa, https://www.bip.Kraków.pl/?dok_id=56832 [accessed: 05.07.2018].

Giffinger R., Fertner C., Kramar H., Kalasek R., Pichler Milanović N., Meijers E. 2007. Smart Cities - Ranking of European medium - sizes cities. Final report, www.smart-cities.eu, [accessed: 05.07.2018].

Gorzelany-Dziadkowiec M., Gorzelany-Plesińska J., Chaba D., Kardaś A., Kozień E., Krzyk P., Kubica I., Kwoczyńska B., Sławińska N. 2015. Wykorzystanie wybranych metod zarządzania w rozwoju regionalnym. Wydawnictwo Uniwersytetu Rolniczego w Krakowie, Kraków.

Jać P., Zapolska K. 2015. Wspomaganie zarządzania zrównoważonym rozwojem polskich metropolii przy wykorzystaniu narzędzi „miasta inteligentnego”. Uniwersytet w Białymstoku.

Jarzemska M., Węglarz A., Wielomska M. 2011. Zrównoważone miasto - zrównoważona energia z perspektywy energetyki przyjaznej środowisku. Warszawa.

Kowalski Ł. 2012. Inteligentne miasta - przegląd rozwiązań. Publikacje Instytutu Geografii i Gospodarki Przestrzennej Uniwersytetu Jagiellońskiego, 116-118.

Kukliński A., Woźniak J. (red.). 2011. Unia Europejska. Dylematy XXI wieku, Kraków.

Mazerant M. (red.). 2012. Inteligentne miasta. Biuletyn Informacyjny Regionalnego Programu Operacyjnego Województwa Łódzkiego na lata 2007-2013, Łódź.

Parteka T. 2012. Inteligentny rozwój miast. Fantom czy trwały paradygmat?. Politechnika Gdańska.

Wdowiarz-Bliska M. 2012. Od miasta naukowego do smart city. Architektura. Czasopismo techniczne. Wydawnictwo Politechniki Krakowskiej, Kraków, 307-308.

Uchwała nr 239 Rady Ministrów z dnia 13 grudnia 2011 r. w sprawie przyjęcia Koncepcji Przestrzennego Zagospodarowania Kraju 2030 (M.P. 2012, poz. 252).

Uchwała nr CXII/1700/14 Rady Miasta Krakowa z dnia 9 lipca 2014 r. w sprawie przyjęcia dokumentu Studium uwarunkowań i kierunków zagospodarowania przestrzennego Miasta Krakowa.

Uchwała Nr LXXV/742/05 Rady Miasta Krakowa z dnia 13 kwietnia 2005 r. w sprawie przyjęcia dokumentu Strategia Rozwoju Krakowa, 21.

Uchwała nr XCIV/2449/18 Rady Miasta Krakowa z dnia 7 lutego 2018 r. w sprawie przyjęcia dokumentu Strategia Rozwoju Krakowa. Tu chcę żyć. Kraków 2030.

Dr Julia Gorzelany

Uniwersytet Rolniczy w Krakowie

Katedra Gospodarki Przestrzennej i Architektury Krajobrazu

30-149 Kraków, ul. Balicka 253c

e-mail: j.gorzelany@ur.Kraków.pl

Mgr inż. Stanisław Lorek

e-mail:s_lorek@wp.pl 